The tropical environment is inhospitable to existing domestic species and presumably McDowell's intention was only to consider how the environment affects the production of cattle. But his paper is cast in more general terms as "climate versus man and his animals", and while it is stated that "to attain the desired level of animal performance all elements contributing to the onvironment and their interactions must be considered", it would also be appropriate to consider how the balance might be swung in man's favour by the recruitment of new species to "his animals".

The adverse effects of high temperature and associated high humidity, or drought, on exotic domestic animals are manifest as decreased food intake, depressed weight gains and recurrrent loss of weight in the dry season, depressed milk yield, and decreased resistance to disease and parasitism. In addition, the fecundity of the stock may be very low. In producing low efficiency the physiological mechanism on which the environment places stress are the animal's ability to dissipate heat, to conserve water and to use nutrients that are of limited availability. Moreover, bchavioural reactions play an important part, as in tolerance of discomfort and the feeding patterns adopted.

Large herbivores that are indigenous to the tropics exhibit adaptations that could be of the greatest value as attributes of domestic stock. Buffalo (Syncerus caffer) and oryx (Oryx gazella) tolerate wide fluctuations in body temperature and so lessen the need to lose water for the purpose of temperature regulation ${ }^{1}$. The eland (Taurotragus oryx) voids faeces of low moisture content and this enables it to gain more preformed water. An estimated $4 \mathrm{l}$. of water per $100 \mathrm{~kg}$ body weight per day is available to the eland from food and metabolic sources, so that the animal can be almost independent of surface water ${ }^{2}$. (Yrant's gazelle (Gazella granti) lives through the dry season without drinking watcr ${ }^{3}$. Ruminants have evolved an effective means of nitrogen conservation by urea-recycling through the salivary glands and those adapted to the arid zone can be expected to be particularly efficient in this regard and to thrive on herbage of exceptionally low protein content. Indigenous tropical ungulates, exemplified by eland ${ }^{4}$ and by wildebeest (Connochaetes taurinus $)^{5}$, have high fertility and fecundity and exhibit a shorter calving interval than cattle. Finally, in their selectivity towards the plants that they graze or browse, indigenous mammals probably exhibit superiority over exotic species, and the antelopes can select a high proportion of the most nutritious parts of plants. If these natural adaptations were harnessed, then the contrasting lack of appropriate physiological and behavioural adapta. tions in eattle, and their restricted ability to acclimatize or acquire immunity to discase, would no longer set the limits to production or to man's contention with climate.

Eland have been domesticated in the Soviet Union ${ }^{6}$ and on a small scale in Southern Africa. Buffalo, blesbok (Damaliscus dorcas) and springbok (Antidorcas marsupialus) have at least reached the stage of "animal keeping". What is needed, however, is the development of such projects on a large scale so that the forms in a state of incipient domestication may be rigorously selected for docility and efficiency and strains produced that can be compared with cattle on a ranching basis. The productive superiority of communities of indigenous large herbivores on range land, at least in Africa, has been convincingly established ${ }^{7,8}$ and currently the means of exploiting this advantago is through game cropping. The technical problems in making a cropping scheme efficient, however, compared with ranching cattle, where the beasts can be rounded up and handled, are formidable. Would it be justified to fully domesticate a new range of species ? I believe it would ${ }^{9}$ : the cost would be high, but so would be the cost of raising the productivity of traditional systems. The four major meat producers-cattle, shoop, goats and pigs-were domesticatod by prehistoric man from species indigenous to S.W. Asia some 6,000 to 9,000 years ago ${ }^{10}$. It seems unnecessary that we should today be limited by his choice.

Yours faithfully,

Department of Zoology,

P. A. JEWELL

University College London, Gower Street, WCl.

${ }^{2}$ Bligh, J., and Harthoorn, A. M., J. Physiol., 1'76, 145 (1965).

${ }^{2}$ Taylor, C. R., and Lyman, C. P., Physiol. Zool., 40, 280 (1967).

${ }^{3}$ Lamprey, H. E., East Afric. Wildlife J., 1, 63 (1963).

${ }^{4}$ Skinner, J. D., Anim. Breed. Abstr., 35, 177 (1967).

${ }^{5}$ Watson, R. M., thesis, Univ:'Cambridge (1967).

${ }^{6}$ 'Treus, V., and Kravchenko, D., Symp. Zool. Soc., Lond., 21, 395 (1968).

Talbot, L. M., Payne, W. J. A., Ledger, H. P., Verdcourt, I. D., and Talbot, M. H., Commonw. Bur. Anim. Breed. Gen. Tech. Comm., 16, 42 (1965).

${ }^{8}$ Crawford, M. A., Vet. Ree., 82, 305 (1968).

Jewell, P.A., in Domestication and Exploitation of P'lants and Animals (Weidenfeld and Nicolson, London, in the press).

${ }^{10}$ Domestication and Exploitation of Plants and Animals (edit. by Ucko, P. J., and Dimbleby, G. W.) (Weidenfeld and Nicolson, London, in the press).

\section{Paraffin Sections}

Sir,--Difficulties I have experienced in finding technical assistance in the preparation of paraffin sections for research work have led me to the discovery that there is a large number of histology technicians (mainly married women) who are keen to do work at home cutting sections. Owing to the sporadic nature of the requirements for paraffin sections by many investigators, and to the difficulties that they have in finding, equipping and supervising competent technicians, it seemed that some arrangement for meeting their requirements with the services of part time technicians might be a useful service.

However, it is hard to assess what the actual demand for such a service might be, and I am therefore writing to ask through your columns if those who are interested would care to address their enquiries to

\section{Yours faithfully,}

Paul D. Byers

146, Harley Street,

London, W1.

Erratum. In the communication "Complex ProteinProdigiosin in Serratia marcescens" by Ramón CruzCamarillo and Atilano A. Sánchez-Zúñiga (Nature, 218, 567 ; 1968) $10,000 \mathrm{~g}$ in the ninth line of the second paragraph should read $100,000 \mathrm{~g}$.

Erratum. In the sixth line of the fifth paragraph of the cornmunication "Ordovician Conodonts from New Zealand" by A. J. Wright (Nature, 218, 664; 1968) trigonious should be spelt trigonius, and in the eighteenth line Llaneilian should be spelt Llandeilian. Cytroniodus in the sixth paragraph should be spelt Cyrtoniodus.

ERratum. In the communication " $80 \mathrm{MHz}$ Photography of the Eruption of a Solar Prominence" by J. P. Wild, K. V. Sheridan and K. Kai (Nature, 218, 536; 1968) the times in the ninth line of the fifth paragraph should read $04 \mathrm{~h} 18 \mathrm{~m}$ and $04^{\mathrm{h}} 30^{\mathrm{m}}$. In the same paragraph Fig. 3 (ii)-(viii) should read Fig. 3 (iii)-(viii). The last sentence of the sixth paragraph should read: "Assuming the shock wave to have originated from near the photosphere when the $H \alpha$ prominence erupted, wo infer a radial shock velocity of $550 \mathrm{~m} \mathrm{~s}^{-1}$, which is typical for such phenomena ${ }^{3}$ ". "The address of the authors of this article is Epping, Now South Wales, and not Sydney. 